Abstracta Iranica

Revue bibliographique pour le domaine irano-aryen

Volume 32-33 | 2013

Comptes rendus des publications de 2009-2010

\title{
Frederik G. McLeod. Theodore of Mopsuestia (The Early Church Fathers)
}

\section{Florence Jullien}

\section{(2) OpenEdition \\ 1 Journals}

\section{Édition électronique}

URL : http://journals.openedition.org/abstractairanica/40854

DOI : 10.4000/abstractairanica.40854

ISSN : 1961-960X

Éditeur :

CNRS (UMR 7528 Mondes iraniens et indiens), Éditions de l'IFRI

\section{Édition imprimée}

Date de publication : 1 décembre 2013

ISSN : 0240-8910

\section{Référence électronique}

Florence Jullien, «Frederik G. McLeod. Theodore of Mopsuestia (The Early Church Fathers) », Abstracta Iranica [En ligne], Volume 32-33 | 2013, document 336, mis en ligne le 01 juillet 2016, consulté le 26 septembre 2020. URL : http://journals.openedition.org/abstractairanica/40854 ; DOI : https://doi.org/ 10.4000/abstractairanica.40854

Ce document a été généré automatiquement le 26 septembre 2020.

Tous droits réservés 


\section{Frederik G. McLeod. Theodore of Mopsuestia (The Early Church Fathers)}

Florence Jullien

\section{RÉFÉRENCE}

Frederik G. McLeod. Theodore of Mopsuestia (The Early Church Fathers). Abingdon (Oxon), 2008, Routledge, Taylor \& Francis, 198 p.

1 Théodore, évêque de Mopsueste (né à Antioche en 352, mort en 428), considéré comme l'«Interprète " par excellence par les communautés syro-orientales, fut a posteriori tenu par leurs détracteurs comme le Père du «nestorianisme». Sont ici traduits une grande partie de textes jusqu'ici non disponibles en anglais ainsi mis à la disposition des chercheurs. L'A. restitue également les traits majeurs de sa spiritualité, de sa pensée théologique et exégétique à travers la littérature secondaire, et présente les principaux aspects de la recherche encore en débat.

\section{AUTEURS}

FLORENCE JULLIEN

EPHE, Paris 